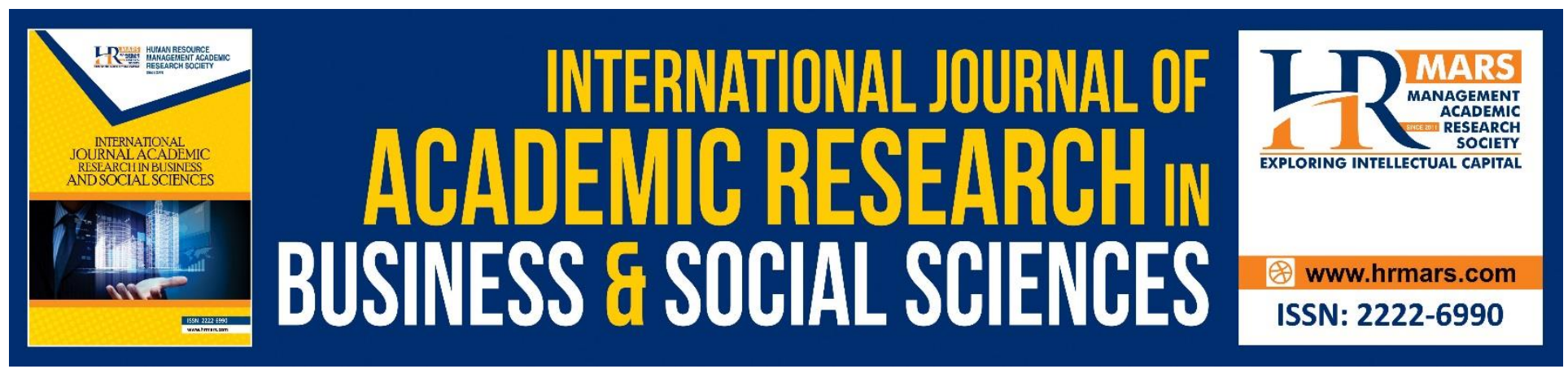

\title{
A Career Development Perspective among Young Adults Cancer Survivors
}

Siti Nur Syuhada Musa, Siti Raba’ah Hamzah, Soaib Asmiran, Ismi Arif Ismail

To Link this Article: http://dx.doi.org/10.6007/IJARBSS/v10-i16/8291

DOI:10.6007/IJARBSS/v10-i16/8291

Received: 11 September 2020, Revised: 17 October 2020, Accepted: 10 November 2020

Published Online: 29 November 2020

In-Text Citation: (Musa et al., 2020)

To Cite this Article: Musa, S. N. S., Hamzah, S. R., Asmiran, S., \& Ismail, I. A. (2020). A Career Development Perspective among Young Adults Cancer Survivors. International Journal of Academic Research in Business and Social Sciences, 10(16), 41-57.

Copyright: (c) 2020 The Author(s)

Published by Human Resource Management Academic Research Society (www.hrmars.com)

This article is published under the Creative Commons Attribution (CC BY 4.0) license. Anyone may reproduce, distribute, translate and create derivative works of this article (for both commercial and non-commercial purposes), subject to full attribution to the original publication and authors. The full terms of this license may be seen

at: http://creativecommons.org/licences/by/4.0/legalcode

Special Issue: Youth and Community Wellbeing: Issues, Challenges and Opportunities for Empowerment V2, 2020, Pg. 41 - 57

http://hrmars.com/index.php/pages/detail/IJARBSS

JOURNAL HOMEPAGE

Full Terms \& Conditions of access and use can be found at http://hrmars.com/index.php/pages/detail/publication-ethics 


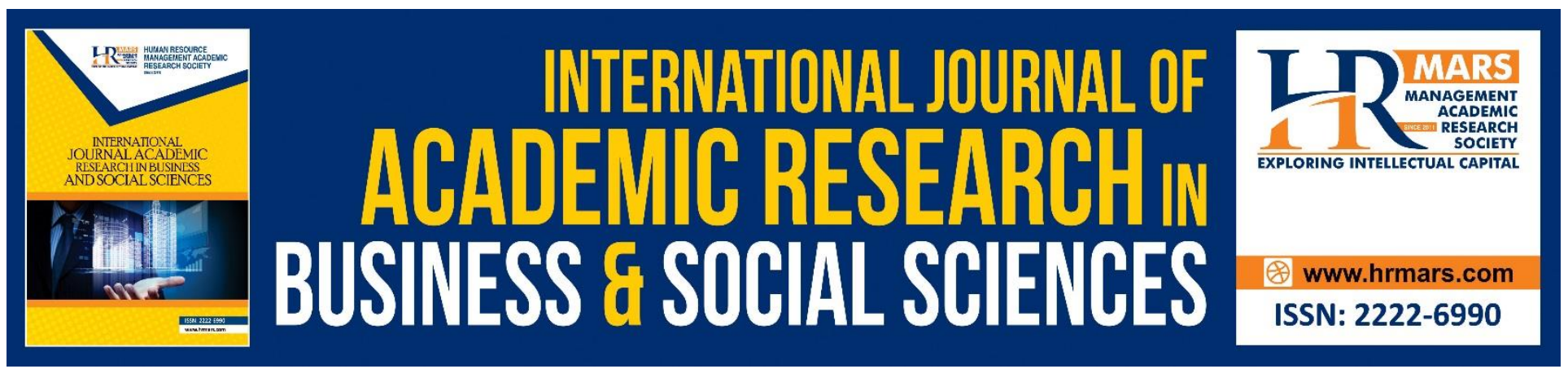

\section{A Career Development Perspective among Young Adults Cancer Survivors}

\section{${ }^{2}$ Siti Nur Syuhada Musa, ${ }^{1,2}$ Siti Raba'ah Hamzah, ${ }^{2}$ Soaib Asmiran, 1,2Ismi Arif Ismail}

${ }^{2}$ Department of Professional Development and Continuing Education, Faculty of Educational Studies, Universiti Putra Malaysia, 43400, UPM, Serdang, Selangor, Malaysia, ${ }^{1}$ Institute for Social Science Studies, Universiti Putra Malaysia, 43400, UPM, Serdang, Selangor, Malaysia. Email: sn.syuhadamusa27@gmail.com, srh@upm.edu.my, soaib@upm.edu.my, ismi@upm.edu.my

\section{Abstract}

The purpose of this paper is to study on the understanding of the concept of career development among cancer survivors who were diagnosed with cancer during their childhood. This study was based on review of past researches on individual factors and career development among cancer survivors using the System Theory Framework. To conduct the literature reviews, the researcher utilized keywords such as career, career development and cancer survivors. From the literatures reviewed, the single factor that contributed to career development among young cancer survivors was the individual factor. Hence, addressing career development (the individual factor), might be important to improve employment outcomes for young cancer survivors. The importance and originality of this study were, it explored career development among young cancer survivors. This paper adopted elements from the System Theory Framework (STF) to derive the individual factor that influenced of career development. It is hoped this research findings will contribute to literatures on the significant factor contributing to career development among young cancer survivors in Malaysia. Keywords: Career Development, Working Life, Cancer Survivors.

\section{Introduction}

Individual career development is a lifetime process that encompasses the growth and change process of childhood, the formal career education at school, and the maturational processes that continue throughout a person's working adulthood and into retirement (Baer, Flexer, Luft and Simmons, 2012). A more contemporary view suggests the individual should take responsibility for planning his/her career which may involve horizontal and vertical movements within and between organizations in order to achieve advancement (Werner \& DeSimone, 2006; Parker \& Inkson, 1999). In the workplace, an individual's career development can be developed by the effort of the organization's program and management function. From this perspective, the management often designs and administers 
various kinds of career programme that enable employees who work in different job groups to match their interests and capabilities with current and future organizational opportunities and changes. These efforts can motivate employees to maintain and support organizational strategies and goals in an era of global competitions (Ismail et al., 2011; Baruch, 2004; Martin, Romero, Valle \& Dolan 2001; Greenhaus et al., 2000). It also enables the organization to achieve a balance between individual career needs and the organization's workforce requirements (Lips-Wiersma \& Hall, 2007). The ability of employees to adapt to these organizational changes can enhance the progression of their career ladders in organizations. They may also create a pleasurable environment and give positive reactions towards their work resulting from their appraisal of their jobs in organizations (Adekola, 2011; Ismail et al., 2011; McShane \& Glinow, 2005; Linz, 2003; Appelbaum \& Shapiro, 2002; Martin et al., 2001; Greenhaus, et al., 2000). They will experience high satisfaction with their jobs which may lead to positive outcomes such as better future in career, providing opportunities for favourable income, an improvement in social status in terms of access to better housing and health care.

However, in contrast, there are individuals who have less opportunity in their career development which is cancer survivors. The development of career among cancer survivors might differ from others. They are disconnected from the labour market, or not engaged in productive activities due to negative physical and psychological health related outcomes (Lucas, Clark, Georgellis, \& Diener, 2004). Having disabilities related to health outcomes may exert little influence on the career development and plans of some individuals, whereas others may find the same disabilities affect their career aspirations, self-esteem and life experiences in general. As Szymanski \& Hanley-Maxwell (1990) explained, 'a disability, in and of itself, does not determine career development but is more accurately perceived as a risk factor potentially influencing career development'.

\section{Landscape of Cancer Survivors}

The number of people living beyond cancer diagnoses reached nearly 15.5 million worldwide in 2014 and is expected to rise to almost 19 million by 2024 (Miller et al., 2016). In Malaysia, a total of 115,238 new cancer cases were registered for the period of 2012-2016. 44.7\% were among males and 55.3\% were among females. The age standardised incidence rates (ASR) were 86.1 for males and 101.6 for females per 100,000 populations. The incidence rates for all sites combined were increased by 2.3 in females and slightly reduced by 0.8 in males per 100,000 populations when comparing the last fiveyear period (2012-2016) with the previous one between 2007 until 2011 (Malaysia National Cancer Registry 2011-2016). Unfortunately, The incidence of cancers in the country is expected to rise due to increasing ageing population in the country, increase in population's exposure to cancer risks with the rapid process of modernization and the growing adoption of unhealthy lifestyles.

Nevertheless, earlier detection, better awareness, and a greater access to better treatment have also contributed to many patients living past five years (Brenner et al., 2012). The ability to cure cancer was one of the great success stories of modern medicine particularly in the high-income countries which also saw an increase in the employment rates among cancer survivors (Mehnert, de Boer and Feuerstein, 2013; Bosetti et al., 2013; Joutard et al., 2012; Verdecchia et al., 2009; Verdecchia et al., 2007 \& Kanavos, 2006). In other words, the success of cancer care is reflected by early detection, prompt treatment and survival improvement after the patient being diagnosed. It could be assumed 
INTERNATIONAL JOURNAL OF ACADEMIC RESEARCH IN BUSINESS AND SOCIAL SCIENCES

Vol. 10, No. 16, Youth and Community Wellbeing: Issues, Challenges and Opportunities for Empowerment V2. 2020, E-ISSN: 2222-6990 @) 2020 HRMARS

cancer patients around the world survived cancer more than ever before due to the success of the medical system such as early diagnoses and more effective treatments.

Approximately 15.5 million cancer survivors currently live in the United States, with the number of survivors expected to increase to 20.3 million by 2026 (American Cancer Society, 2016). Whereas in Malaysia, a Study on Cancer Survival 2018 (National Cancer Registry Department, National Cancer Institute) was the first population-based cancer survival study report on the findings of a five-year relative survival for 15 types of cancers in Malaysia. The survival rate was higher in women and the younger patients aged $15-44$ years who comprised $21 \%$ of the sample. The study also revealed that the cancer survival estimate in Malaysia was comparable to that of other Asian countries, and the pattern was similar with that of other studies for similar types of cancer. However, the survival rate in Malaysia was lower compared to that in Australia, New Zealand, the USA and most European countries. In Malaysia, for many common types of cancer, especially those detected at an early stage, the long-term survival rate is now above $80 \%$ (The Malaysian Pediatric Association, 2012). As a result, the population of cancer survivors is steadily increasing. This has led to a growing number of studies on cancer survivors and the consideration of survivorship as a major factor in the continuum of care (McCabe, 2007; Rowland et al., 2006; Ayanian \& Jacobsen, 2006; Grunfeld, 2006). The overarching treatment of cancer not only to ensure cure, but also to allow the cancer survivors to have normal growth and development in order to realize their full potential as productive and healthy adults so they can focus more on developing their future career. However, the initial experience during cancer treatment had changed the outlook of the patient's altogether; its impact was so negatively powerful that it altered not only the physical appearance of the individual but the inner self as well. They were faced with a unique set of challenges after the diagnosis including the thought of the ability to maintain their work and educational goals during the highly transitional time (Langeveld et al., 2003). Psihogios et al. (2018) found supporting evidence that college personnel do indeed work with survivors. In their survey of staff from college health centers and offices of disabilities from 24 colleges and universities in the Philadelphia area, they found nearly $90 \%$ had provided services to a young adult survivor of childhood cancer within the past two years.

To date, there has been a scant research related to the career development of cancer survivors. Initially researches on cancer survivors focused on curing cancer and on planning, delivering, and monitoring the effects of cancer treatment. More recently, cancer survivorship research has begun to focus on the cancer survivor as a person, including the multiple facets of survivors' quality of life (Dietz \& Mulrooney, 2011; Rowland, 2008; Langeveld, Stam, Grootenhuis, and Last, 2007; Dimitra, 2014). Topics such as cancer survivors' cancer-related fatigue, positive affect, life satisfaction, and spirituality were explored. Yet cancer survivorship research has been slow to recognize the role of work and career issues in cancer survivors' quality of life, and interventions directed at reemployment and return-to-work after treatment lagged behind other quality of life interventions (Hoving, Broekhuizen and Frings-Dresen, 2009).

With the limited research focusing on a very small component of the career development, significant knowledge gaps related to the concept of career development of cancer survivors existed. These knowledge gaps must be addressed in order to gain a better understanding of the factors influencing 
the impact of career development process of cancer survivors and to develop interventions that might improve the career development of cancer survivors in Malaysia. Therefore, this study focused on young adults cancer survivors who were diagnosed with cancer in their early childhood years (below 14 years) and who completely survived from cancer until now. This study was to find out their career development. It is also to facilitate more discussions and researches related to the career development of these young cancer survivors with the goal of increasing employment and overall participation in the broader society. The present scope of study was designed to investigate the development of cancer survivors' care processes in Malaysia through an overview of career development and factors that underpinned their career development.

\section{Methodology}

This paper is a conceptual review based on review of past studies and on the development of a model of career development, cancer survivors covering available international literatures and online data. The process of retrieving the literatures began in March, 2020 to August, 2020. The selected article was based on the year from 2014 until 2020. The selection of articles was based on keywords as suggested by Strauser, Jones, Tansey, Chan (2015) and relevant literatures using keyword search that led to a successful systematic review. In the process, keyword such as career development, working life and young cancer survivors were used such as Google Scholar and Emerald Insight. Science Direct and SAGE were used to search for supporting materials and resources relevant to the study. The review of 17 past studies and the development of a model of career development are shown below.

\section{Cancer Survivors and Career Development}

A short background on the origins of the term and a review of the existing career development among young cancer survivors' debate are necessary to grasp where this study fitted into the context of other academic literatures, and more importantly to point out the gap in the ongoing debate. In terms of definition, there are at least three distinct phases associated with cancer survival. They are; (1) acute survival - where diagnosis and therapeutic intervention dominate and the time from diagnosis to the end of initial treatment; (2) extended survival - when cancer is in remission, the role of doctors and nurses diminishes and psychological distress begins which is the transition from treatment to extended survival, fear of cancer recurrence and physical limitations become manifest; and (3) permanent survival, roughly equated with 'cure' also known as long-term survival (Mullan, 1985). Mullan writes, "No matter how long we live, cancer patients are survivors - at once wary and relieved, bashful and proud"(3, p.272).

Young adult cancer survivors are one group of individuals with chronic health conditions who were negatively impacted in the area of career development and employment (Strauser, 2014). Young cancer survivors aged 15-39 years were historically understudied research population (Kent et al., 2012). Young cancer survivors might not have the opportunity to develop their skills, or to have necessary experiences, to develop effective career and work behaviours and might have difficulty finding employment due to the results of their cancer and associated treatment (Strauser et al., 2010).

Career development is a lifelong developmental process that is influenced by an individual's learning experiences and characteristics of different environments. Factors such as an individual's abilities, 
gender, education, interests, and culture may influence relationships and performance in a working environment. When these factors are applied to the career realm, the implication is one of a complex and dynamic relationship between young cancer survivors and career development (Szymanski, Hershenson, Enright \& Ettinger, 1996). In addition many individuals with disabilities are unable to meet their most basic human needs independently, often creating a state of dependence with no real promise for achieving higher states of vocational or career functioning (Strauser, 2014). The cancer survivors often face difficulties and challenges to work or return to work after receiving treatment (Bouhnik et al., 2015). As survival rates of the young diagnosed with cancer have increased, it is therefore critical to understand how the cancer experience affects functioning, especially in terms of career development. Young cancer survivors have to suspend normative development while managing active treatment. Specifically, when coping with cancer they can stall the progress in decision-making and planning for future careers (Noll et al., 2007; Bleyer 2007; Stern et al., 1993 \& Stern et al., 1991). Past researches proved young adults who survived childhood cancer, experienced problems in obtaining and maintaining employment (Kirchhoff et al., 2010; Stern et al., 2010; Pang et al., 2008; de Boer, Verbeek, \& van Dijk, 2006; Stern, Norman, \& Zevon, 1991).

Previous researches indicated young cancer survivors experienced higher levels of unemployment and often experienced career development problems such as limited work skills, unclear or unrealistic career expectations, and poor social skills, all of which contributed to difficulties in obtaining and maintaining employment and often led to decreased quality of life (Strauser, Wagner, Wong, \& O'Sullivan, 2013; Kirchhoff et al., 2010; Stern et al., 2010; de Boer, Taskila, Ojaja“rvi, van Dijk, \& Verbeek, 2009; Pang et al., 2008; de Boer, Verbeek, \& van Dijk, 2006; Stern, Norman, \& Zevon, 1991). However, a study by Stern et al., (1991) found young cancer patients showed a greater tendency to prematurely foreclose on a career choice than did healthy youths. This showed young cancer survivors who were looking forward to fulfilling some of their dreams, career ambitions or plans, viewed these as lost ambitions or opportunities.

When compared to their non-cancer counterparts, young cancer survivors demonstrated higher prevalence of functional limitations and participation restrictions that interfered with their employment, educational attainment, and other social outcomes (Gurney et al., 2009; Ness at al., 2008; Crom et al., 2007; Ness et al., 2006 \& Ness et al., 2005). Specifically, survivors of childhood cancer were found to be five times more likely to be unemployed compared to their non-cancer counterparts (de Boer, 2006). They also had nearly 15 times the risk for not participating in school or work when compared with their healthy siblings (Ness et al., 2005). A study on parents with young adult survivors of childhood cancer found employment concerns and a lack of career development and employment resources for their young adult children were a major concern and were associated with increased levels of parental stress (Freeman et al., 2010).

\section{Factors Influencing Career Development using The System Theory Framework}

In this study, the factors of career development influences were based on the Systems Theory Framework of career development (McMahon \& Patton, 1995; Patton \& McMahon, 1997, 1999, 2006; Patton \& McMahon, 2014). The aim of STF is to emphasise two general influences of career theory, namely content and process (Patton \& McMahon, 2014). Content influences consist of 
intrapersonal variables, for example personality, gender, abilities and age, as well as contextual variables which consist of the context in which they live, including their social relations, organisations with whom they interact, and the environment in which they live (McMahon et al., 2004; McMahon \& Watson, 2008). Within the framework these influences are represented as three interconnected systems, namely the individual system, the social system and the environmental-societal system (McMahon et al., 2004; Patton \& McMahon, 2014). According to McMahon and Watson (2008), the STF makes provision for the interaction and changing nature of these influences and is thus conceptualised as a dynamic, open system. The process influences comprise three different elements. The first one is referred to as recursive interaction within the individual, as well as between the individual and his or her context (McMahon et al., 2004; Patton \& McMahon, 2014).

The second process influence is known as change over time and "emphasises how recursive interaction contributes to the micro-process of career decision making and the macro-process of change over time" (McMahon et al., 2004, p.14). The third process influence is concerned with the impact of chance on career development (McMahon et al., 2014; McMahon \& Watson, 2008; Patton \& McMahon, 2014). This framework is built on the constructs of information, career problem solving, and decision making. Individuals who lack information or have low levels of readiness experience employment difficulties related to job acquisition and maintenance and may display affective and behavioral states that contribute to negative employment outcomes (Strauser, Zanskas \& Lustig 2011). Research by Hall \& LaCroix, (2015) found the STF elements of learning such as creating a learning environment, the content of learning, and reflection on learning were applied in a clinical supervision experience that was shown to be beneficial to participants. Other researchers had identified the utility of the STF in guiding research activities and Byrne (2007) used the STF to classify the factors influencing the decision to study speech pathology.

\section{Individual factor}

The individual system comprises both intrapersonal influences that have been presented in existing career theories, such as personality, values, and interests, as well as those influences that have traditionally been under-represented in existing career theories, for example gender, age, selfconcept, health, ability, disability, physical attributes, beliefs, personality, interests, values, aptitudes, skills, world of work knowledge, sexual orientation and ethnicity (Patton \& McMahon, 2014). All individuals have these intrapersonal influences, but they are different for each individual (Patton \& McMahon, 2014).

Study by Strauser et al., (2015) stated that individual factors such as age at diagnosis had indirect influences on career readiness through emotional health and vocational identity among cancer survivors. Diagnosed at older ages was related to clear vocational identity, which in turn correlated with higher career readiness. However, Raque-Bogdan, (2013) stated that experiencing breast cancer at a young age contributing to an increased desire for work to provide a sense of meaning as well as financial security and insurance. In addition, Pang et al., (2008) focus on socio-demographic variables and found that, younger age and female gender are associated with higher risks of having never been employed. Szilagy et al., (2019) stated that a gender difference, where female participants are more likely to choose health-related professions than men among cancer survivors. Taskila et al., (2004) 
found that the education plays a role on cancer survivors employment. Strauser et al., (2013) found differences for unemployment status, educational attainment and personal income towards career readiness among cancer survivors. Next, personal factors such as race significantly affect the career and employment of cancer survivors. For example, Kirchhoff et al., (2010) have documented that female survivors or African American, Hispanic, and mixed race survivors are more likely to report health-related unemployment whereas only African American or mixed race survivors are more likely to be unemployed but seeking work (Kirchhoff et al., 2010). In addition, survivors' personal resources such as optimism are also found to be important for stimulating survivors' personal growth and increasing their commitment to work (Demerouti et al., 2001; Hakanen \& Lindbohm, 2008).

\section{Social Influences Factor}

Social influences or the contextual system in STF is separated into two smaller systems namely the social system and the environmental-societal system. Individuals are relational and they construct a sense of self through interaction with those around them (Patton \& McMahon, 2014). Different life roles only exist due to the relationship that exists with the larger system (Patton \& McMahon, 2014). The social system represents the principal social influences with which individuals interact, such as peers, family, media, community groups, workplace, and education institutions (McMahon \& Watson, 2008; Patton \& McMahon, 2014). Each of these social structures is also a source of beliefs, values and attitudes that may get taught to the individual in a diversity of ways (Patton \& McMahon, 2014). The influence that these different groups can have on an individual can be long-lasting, but also change at different times throughout an individual's life as he/she move between social influences (Patton \& McMahon, 2014). As can be seen in Figure 1, the individual and the social systems function within the broader system, namely that of the society and the environment (McMahon \& Watson, 2008; Patton \& McMahon, 2014). This is known as the environmental-societal system. Although subsystems of the environmental-societal system, such as political decisions, historical trends, globalization, socio-economic status, employment market, and geographical location seem to have a less direct impact on the career development of the individual, it is none the less profound. In other words, it can be viewed as a ripple effect, where the slightest movement in the outer circle is felt by the smallest circle in the centre. Therefore, in the case of the STF, it will be the individual, social and environmental-societal factors.

At educational institution, students will generate knowledge and develop various skills needed for their individual development (Eriksson, Welander, \& Granlund, 2007). For cancer survivors, returning to school/university represents an important milestone in life (Boonen \& Petry, 2012). Although they were looking forward to come to the school again, but somehow they may experience a volatile challenges following re-entry (Bonneau et al., 2011). However, support from the education institution may hindered the barrier of cancer survivor's reintegration which can give positive impact on their career development in the future. Furthermore, school helps adolescents in critical thinking about their career-related goals and social values attached to these goals (Germeijs, Verschueren, \& Soenens, 2006). This is whereby social system such as education institution should give much attention to cancer survivors to ensure the long-term success of survivors that can facilitate the engagement of survivors with the education institution, enhance the quality of learning environments, and pave the way for survivors' continued development. 
In addition, Bashore and Breyer, (2017) stated that the survivors focused more on their peer relationships and the social impact of either returning to school after an extended absence rather than having to reengage in class attendance for an education. This emphasize on the peer's relationship deem important contributor to the development of cancer survivor's career and life. The role of perceived social support such as family and friend, will ensure the security and companionable in their surroundings (Bozo et al., 2009). In the same vein, Szilagy et al., (2019) found that social and family circumstances have substantial impact on the choice of a health-related career among cancer survivors. Next, social-environmental factors reveal that the workplace shows a significant impact on career development of cancer survivor. For example, Hamzah et al., (2020) stated that the understanding and recognition by the organization deem important contributor toward cancer survivor's career engagement. The study also mentioned the strong correlation between atmosphere in working environment and career engagement among cancer survivors (Hamzah et al., 2020). However, Moskowitz, Todd, Chen, and Feuerstein (2014) report that workplace problems are linked to lower levels of work ability and survivors reporting workplace problems are more likely to lose or leave a job because of cancer. Hence, it is crucial to study the factors of career development among cancer survivors because they require more support and information especially with respect to reintegrating into the world of work. 
INTERNATIONAL JOURNAL OF ACADEMIC RESEARCH IN BUSINESS AND SOCIAL SCIENCES

Vol. 10, No. 16, Youth and Community Wellbeing: Issues, Challenges and Opportunities for Empowerment V2. 2020, E-ISSN: 2222-6990 @ 2020 HRMARS

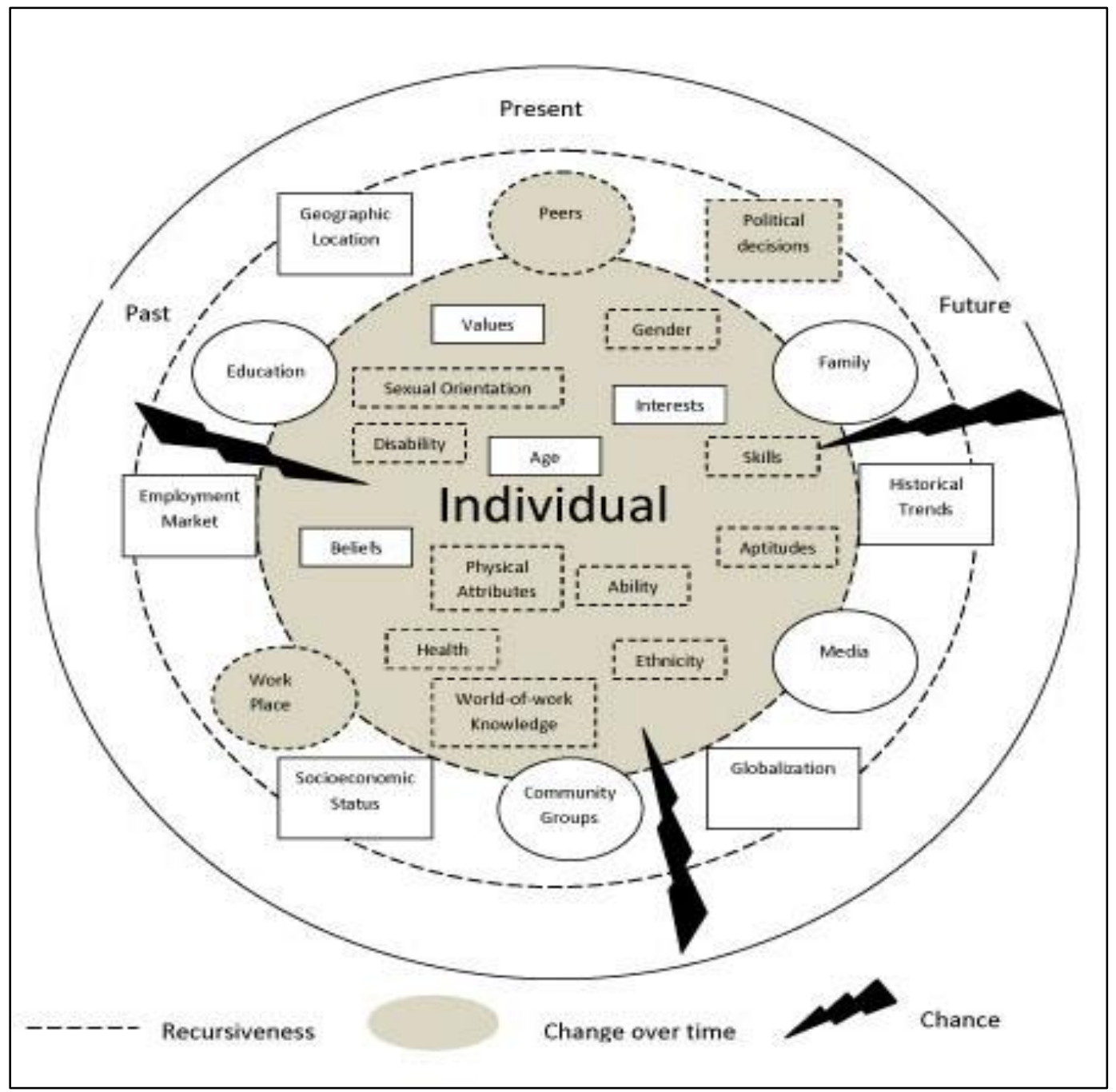

Source: McMahon \& Patton, 1995

Figure 1: The System Theory Framework of Career Development 
INTERNATIONAL JOURNAL OF ACADEMIC RESEARCH IN BUSINESS AND SOCIAL SCIENCES

Vol. 10, No. 16, Youth and Community Wellbeing: Issues, Challenges and Opportunities for Empowerment V2. 2020, E-ISSN: 2222-6990 @ 2020 HRMARS

\section{Proposed Conceptual Framework}

Based on the above discussion, we developed a conceptual framework as depicted in Figure 2.

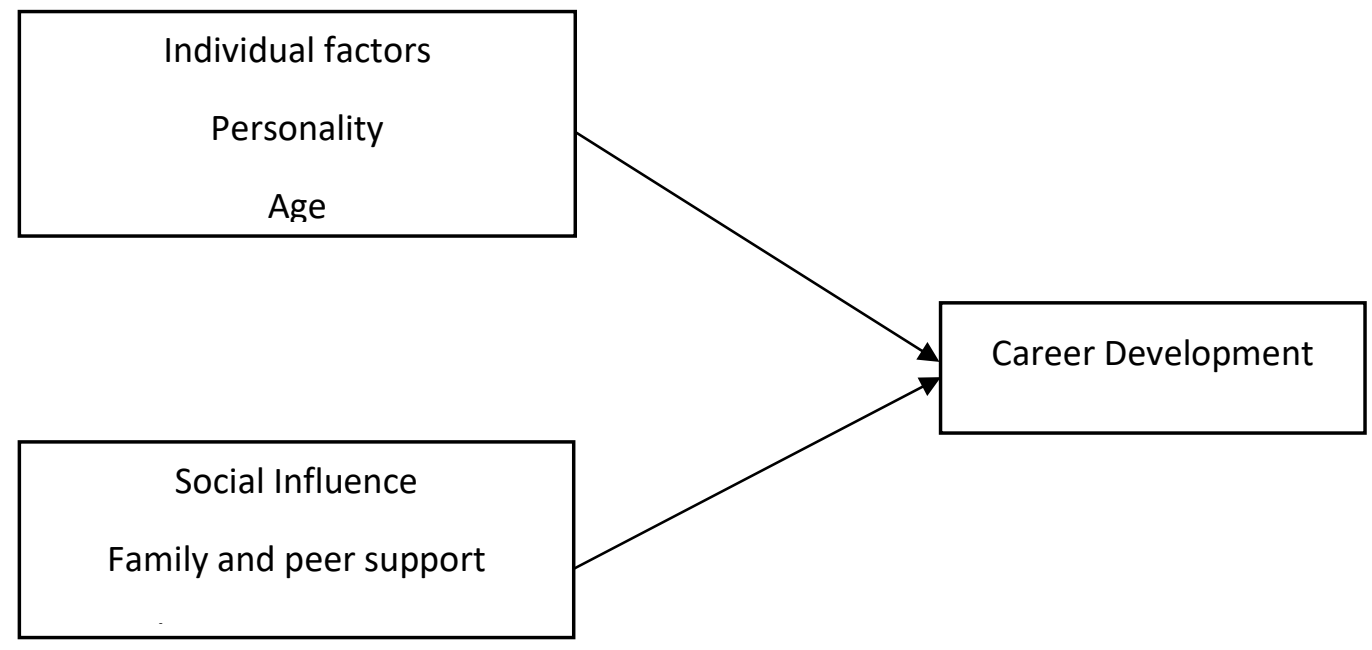

Figure 2: The author proposed conceptual framework

\section{Conclusion and Recommendations}

The intent of this article was to provide an introduction to a domain factor to provide a framework for all individuals involved in the career development of young adult cancer survivors with the goal of improving participation in work related activities and overall participation in broader society. The framework was based on The System Theory of Career Development. To further explore the reported impacts of cancer survivors on career development, the following issues require further considerations. Firstly, the people's perceptions on individuals who are influenced by the presence of cancer survivors. This means stereotyping occurs within the workplace which can impact on career development, especially through equitable training and promotion opportunities. Secondly, further explorations should find out whether confidence and self-esteem issues are associated with the history of cancer which may or may not have an impact on career development. Next, the responsibility for career development among young cancer survivors should be addressed. Should the responsibility lies on the individual, the employer, or a joint partnership and whether the management supports career development and does it apply equitably? The importance of practical support at the work place and health care providers had been reported in some studies on cancer and work. According to a finished study on social support at the work place and occupational health services, practical support was most needed from the supervisors in the form of taking the illness into consideration when planning and managing the work tasks of cancer survivors. From the occupational health personnel, support was especially needed by evaluating the working conditions in the light of the cancer survivors' ability to cope at work (Taskila et al., 2006). The information from this communiqué will enhance in tailoring the project, harmonization of pertinent allotment of resources and dissemination of cancer care. 
The scope of this study was designed to investigate the need of the development of cancer survivorship care processes to be enacted within Malaysia by creating an overview of career development and factors that underpinned young cancer survivors' career development. Studies suggested long-term follow up programmes and interventions to improve employment outcomes should be implemented in Malaysia and not only focusing on their cancer treatment follow up such as physical health, neurocognitive problems, and screening for mental health issues, but should also address career development among young cancer survivors. Malaysia has several care supports such as National Cancer Council, National Cancer Society of Malaysia's (NCSM), CARES Parent Support Group and Sarawak Children's Cancer Society Sarawak (SCCS). This care supports play a vital role in emotional support where the cancer survivors can share their personal experiences with the groups and gain a sympathetic and emphatic network to get them through the traumatic experiences of cancer. However, there are no long-term follow up programmes for career development. These are within the realm of social science to come up with initiatives. Considerations of cost, feasibility, making the best use of current resources, empowering young people and parents, developing shared models of care, and building upon existing evidence on survivorship care pathways are all important especially in their career development. Hence, the program of career development long-term follow up should be taken into account to maximize employment potentials among young cancer survivors in Malaysia.

\section{Conflict of Interest}

The authors declare that they have no competing interest in conducting this study.

\section{Acknowledgement}

The authors gratefully acknowledge the funding support provided by the Universiti Putra Malaysia (9597500) under the Research Management Centre, Ministry of Education Malaysia (2018-2020).

\section{References}

Adekola, B. (2011). Career Planning and Career Management as Correlates for Career Development and Job Satisfaction. A Case Study of Nigerian Bank Employees. Australian Journal of Business and Management Research, 1(2): 100-112.

Appelbaum, S. H., Ayre, H., \& Shapiro, B. T. (2002). Career management in information technology: a case study. Career development international, 7(3): 142-158.

Armstrong, M. (1996). A handbook of personnel management practice. Kogan Page.

Ayanian, J. Z., \& Jacobsen, P. B. (2006). Enhancing research on cancer survivors. Journal of Clinical Oncology, 24(32): 5149-5153.

Baruch, Y. (2004) Transforming careers: From linear to multidirectional career paths-organizational and individual perspectives. Career Development International 9(1): 58-73.

Bashore, L., \& Breyer, E. (2017). Educational and career goal attainments in young adult childhood cancer survivors. Journal for Specialists in Pediatric Nursing, 22(2): e12180.

Boonen, H., \& Petry, K. (2012). How do children with a chronic or long-term illness perceive their school re-entry after a period of homebound instruction?. Child: Care, health and development, 38(4): 490-496. 
Bonneau, J., Lebreton, J., Taque, S., Chappe, C., Bayart, S., Edan, C., \& Gandemer, V. (2011). School performance of childhood cancer survivors: mind the teenagers!. The Journal of Pediatrics, 158(1): 135-141.

Bosetti, C., Bertuccio, P., Malvezzi, M., Levi, F., Chatenoud, L., Negri, E., \& La Vecchia, C. (2013). Cancer mortality in Europe, 2005-2009, and an overview of trends since 1980. Annals of oncology, 24(10): 2657-2671.

Bouhnik, A. D., Bendiane, M. K., Cortaredona, S., Teyssier, L. S., Rey, D., Berenger, C., \& VICAN Group. (2015). The labour market, psychosocial outcomes and health conditions in cancer survivors: protocol for a nationwide longitudinal survey 2 and 5 years after cancer diagnosis (the VICAN survey). BMJ Open, 5(3): e005971.

Boudreaux, M. A. (2001). Career development: What is its role in human resource development. In Proceedings of the Academy of Human Resource Development (pp. 805 812). Baton Rouge, LA: Academy of Human Resource Development.

Crom, D. B., Lensing, S. Y., Rai, S. N., Snider, M. A., Cash, D. K., \& Hudson, M. M. (2007). Marriage, employment, and health insurance in adult survivors of childhood cancer. Journal of Cancer Survivorship, 1(3): 237-245.

Demark-Wahnefried, W., Aziz, N. M., Rowland, J. H., \& Pinto, B. M. (2005). Riding the crest of the teachable moment: promoting long-term health after the diagnosis of cancer. Journal of Clinical Oncology, 23(24): 5814-5830.

Dimitra, T. (2014). The Views of Preschool Students on the Issue of Quality of Education in Kindergartens: A Survey of "Infant Voices". Multilingual Academic Journal of Education and Social Sciences, 2(2), 53-74.

Dietz, A. C., \& Mulrooney, D. A. (2011). Life beyond the disease: relationships, parenting, and quality of life among survivors of childhood cancer. Haematologica. 96(5): 643-645.

De Boer, A. G., Verbeek, J. H., \& van Dijk, F. J. (2006). Adult survivors of childhood cancer and unemployment. Cancer, 107(1): 1-11.

De Boer, A. G., Taskila, T., Ojajärvi, A., Van Dijk, F. J., \& Verbeek, J. H. (2009). Cancer survivors and unemployment: a meta-analysis and meta-regression. Jama, 301(7): 753-762.

Eriksson, L., Welander, J., \& Granlund, M. (2007). Participation in everyday school activities for children with and without disabilities. Journal of Developmental and Physical Disabilities, 19(5): 485-502.

DeSimone, R. L., Werner, J. M., \& Harris, D. M. (2002). Human resource development (3rd ed.) Orlando, FL: Harcourt College. 9812438548,9789812438546

Ferreira, J. A., Santos, E. J., Fonseca, A. C., \& Haase, R. F. (2007). Early predictors of careerdevelopment: A 10-year follow-up study. Journal of Vocational Behavior, 70(1): 61-77.

Freeman, K., O’Dell, C., \& Meola, C. (2004). Childhood brain tumors: parental concerns and stressors by phase of illness. Journal of Pediatric Oncology Nursing, 21(2): 87-97.

Flexer, R. W., Baer, R. M., Luft, P. J., \& Simmons, T. J. (2012). Transition planning for secondary students with disabilities 4th edition. ISBN-9780132822671

Germeijs, V., Verschueren, K., \& Soenens, B. (2006). Indecisiveness and high school students' career decision-making process: Longitudinal associations and the mediational role of anxiety. Journal of Counseling Psychology, 53(4): 397-410. 
INTERNATIONAL JOURNAL OF ACADEMIC RESEARCH IN BUSINESS AND SOCIAL SCIENCES

Vol. 10, No. 16, Youth and Community Wellbeing: Issues, Challenges and Opportunities for Empowerment V2. 2020, E-ISSN: 2222-6990 @) 2020 HRMARS

Gilley, J. W., Eggland, S. A., \& Gilley, A. M. (2002). Principles of human resource development. Cambridge: Perseus Books.

Greenhaus, J. G, Callanan, G. A, Godshalk, V. M. (2000) Career management. New York: The Drydent Press.

Grunfeld, E. (2006). Looking beyond survival: how are we looking at survivorship?. Journal of Clinical Oncology, 24(32): 5166-5169.

Gurney, J. G., Krull, K. R., Kadan-Lottick, N., Nicholson, H. S., Nathan, P. C., Zebrack, B., \& Ness, K. K. (2009). Social outcomes in the childhood cancer survivor study cohort. Journal of Clinical Oncology, 27(14): 2390-2395.

Hall, M. E., \& LaCroix, J. (2015). Critical career supervision in independent practice: A counselor and supervisor-learning system perspective. Australian Journal of Career Development, 24: 136140.

Hirschi, A. (2009). Career adaptability development in adolescence: Multiple predictors and effect on sense of power and life satisfaction. Journal of Vocational Behavior, 74(2): 145-155.

Ismail, A., Daud, N. G., \& Madrah, H. (2011). Relationship between career program characteristics and job satisfaction in a city based local authority. Annals of the Alexandru loan Cuza University, 58(1): 270-279.

Ismail, A., Madrah, H., Aminudin, N., \& Ismail, Y. (2013). Mediating role of career development in the relationship between career program and personal outcomes. Makara Hubs- Asia, 17(1): 4354.

Joutard, X., Paraponaris, A., Teyssier, L. S., \& Ventelou, B. (2012). Continuous-time Markov model for transitions between employment and non-employment: the impact of a cancer diagnosis. Annals of Economics and Statistics, 107(108): 239-265.

Kanavos, P. (2006). The rising burden of cancer in the developing world. Annals of Oncology, 17(8): viii15-viii23.

Kirchhoff, A. C., Leisenring, W., Krull, K. R., Ness, K. K., Friedman, D. L., Armstrong, G. T., \& Robison, L. L. (2010). Unemployment among adult survivors of childhood cancer: a report from the childhood cancer survivors study. Medical Care, 48(11): 1015-1025.

Langeveld, N. E., Stam, H., Grootenhuis, M. A., \& Last, B. F. (2002). Quality of life in young adult survivors of childhood cancer. Support Care Cancer, 10(2002): 579-600.

Langeveld, N. E., Ubbink, M. C., Last, B. F., Grootenhuis, M. A., Voute, P. A., \& De Haan, R. J. (2003). Educational achievement, employment and living situation in long-term young adult survivors of childhood cancer in the Netherlands. Psycho-Oncology, 12(3): 213-225.

Linz, S. J. (2003). Job satisfaction among Russian workers. International journal of manpower, 24(6): 626-652.

Lips-Wiersma, M., \& Hall, D. T. (2007). Organizational career development is not dead: A case study on managing the new career during organizational change. Journal of Organizational Behavior, 28(6): 771-792.

Lucas, R. E., Clark, A. E., Georgellis, Y., \& Diener, E. (2004). Unemployment alters the set point for life satisfaction. Psychological Science, 15(1): 8-13.

Martin, A. F., Romero, F. P., Valle, C. R., Dolan, S. L. (2001), Corporate business Strategy, career management and recruitment: Do Spanish firms adhere to contingency model? Career Development International, 6(3): 149-155. 
Mehnert, A., De Boer, A., \& Feuerstein, M. (2013). Employment challenges for cancer survivors. Cancer, 119(S11): 2151-2159.

Merchant Jr, R. C. (2010). The role of career development in improving organizational effectiveness and employee development. Florida Department of Law Enforcement.

Mertens, A. C. (2008). The impact of limitations in physical, executive, and emotional function on health-related quality of life among adult survivors of childhood cancer: A report from the Childhood Cancer Survivor Study. Archives of physical medicine and rehabilitation, 89(1): 128136.

McCabe, M. S. (2007). Looking Beyond Survival--Survivorship care is critical to the future of oncology. Oncology, 21(3): 398-398.

McLagan, P. A. (1989). The models: A volume in models for HRD practice. Alexandria, VA: American Society for Training and Development.

McShane, S. L., \& Glinow, V. M. A. (2005). Organizational behavior (3rd ed.). New York: McGraw Hill.

Moran, J. R., Short, P. F., \& Hollenbeak, C. S. (2011). Long-term employment effects of surviving cancer. Journal of Health Economics, 30(3): 505-514.

Mullan, F. (1985). Seasons of survival: reflections of a physician with cancer. New England Journal of Medicine, 313: 270-273.

Nankervis, A., Compton, B., \& Baird, M. (2005), Strategic Human Resource Management: Strategies and processes, 5 th ed, Thomson Learning, Melbourne.

National Cancer Registry Department, National Cancer Institute (2018), available at: http://nci.moh.gov. my/index.php/ms/main-menu-2/laporanYearofPublication:2018.

Ness, K. K., Mertens, A. C., Hudson, M. M., Wall, M. M., Leisenring, W. M., Oeffinger, K. C., \& Gurney, J. G. (2005). Limitations on physical performance and daily activities among long-term survivors of childhood cancer. Annals of Internal Medicine, 143(9): 639-647.

Ness K. K., Gurney J. G., Zeltzer L., Leisenring W., Mulrooney D., \& Nathan P. (2008). The impact of limitations in physical, executive, and emotional function on health-related quality of life among adult survivors of childhood cancer: A report from the childhood cancer survivors study. Archives of Physical Medicine and Rehabilitation, 89: 128-136.

Ness, K. K., Wall, M. M., Oakes, J. M., Robison, L. L., \& Gurney, J. G. (2006). Physical performance limitations and participation restrictions among cancer survivors: a population-based study. Annals of epidemiology, 16(3): 197-205.

Noll, R. B., \& Kupst, M. J. (2007). Commentary: The psychological impact of pediatric cancer hardiness, the exception or the rule? Journal of Pediatric Psychology, 32(9): 1089-1098.

Pang, J. W., Friedman, D. L., Whitton, J. A., Stovall, M., Mertens, A. C., Robison, L. L., \& Weiss, N. S. (2008). Employment status among adult survivors in the Childhood Cancer Survivor Study. Pediatric blood \& cancer, 50(1): 104-110.

Parker, P., \& Inkson, K. (1999). New forms of career: The challenge to human resource management. Asia Pacific Journal of Human Resources, 37(1): 76-85.

Patton, W., \& McMahon, M. (2014). Career development and systems theory: Connecting theory and practice. (3rd edn.). Rotterdam: Sense Publishers.

Peterson, G. W., Sampson, J. P., \& Reardon, R. C. (1991). Career development and services: A cognitive approach. Pacific Grove, CA: Brooks/Cole. 
INTERNATIONAL JOURNAL OF ACADEMIC RESEARCH IN BUSINESS AND SOCIAL SCIENCES

Vol. 10, No. 16, Youth and Community Wellbeing: Issues, Challenges and Opportunities for Empowerment V2. 2020, E-ISSN: 2222-6990 @) 2020 HRMARS

Raque-Bogdan, T. L. (2013). The work life and career development of young working women who are breast cancer survivors: A qualitative study. Journal in Counseling Psychology, 62(4): 655-69.

Rowland, J. H., Hewitt, M., \& Ganz, P. A. (2006). Cancer survivorship: a new challenge in delivering quality cancer care. Journal of Clinical Oncology, 24(32): 5101-5104.

Sampson, J. P., Reardon, R. C., Peterson, G. W., \& Lenz, J. G. (2004). Career counseling and services: A cognitive information processing approach. Belmont, CA: Thomson/Brooks/Cole.

Saunders, D. E., Peterson, G. W., Sampson, J. P., \& Reardon, R. C. (2000). Relation of depression and dysfunctional career thinking to career indecision. Journal of Vocational Behavior, 56(2): 288298.

Stern, M., Krivoy, E., Foster, R. H., Bitsko, M., Toren, A., \& Ben-Arush, M. (2010). Psychosocial functioning and career decision-making in Israeli adolescent and young adult cancer survivors. Pediatric blood \& cancer, 55(4): 708-713.

Stern, M., Norman, S. L., \& Zevon, M. A. (1991). Career development of adolescent cancer patients: A comparative analysis. Journal of counseling psychology, 38(4): 431-439.

Strauser, D., Feuerstein, M., Chan, F., Arango, J., da Silva Cardoso, E., \& Chiu, C. Y. (2010). Vocational services associated with competitive employment in 18-25 year old cancer survivors. Journal of Cancer Survivorship, 4(2): 179-186.

Strauser, D., Zanskas, S., \& Lustig, D. (2011). Career readiness and individuals with disabilities. Rehabilitation Research, Policy, and Education, 25(3-4): 173-179.

Strauser, D., Wagner, S., Wong, A. W., \& O’Sullivan, D. (2013). Career readiness, developmental work personality and age of onset in young adult central nervous system survivors. Disability and rehabilitation, 35(7): 543-550.

Strauser, D. R., Jones, A., Chiu, C. Y., Tansey, T., \& Chan, F. (2015). Career development of young adult cancer survivors: A conceptual framework. Journal of Vocational Rehabilitation, 42(2): 167176.

Strauser, D., Klosky, J. L., Brinkman, T. M., Wong, A. W., Chan, F., Lanctot, J., \& Ness, K. K. (2015). Career readiness in adult survivors of childhood cancer: a report from the St. Jude Lifetime Cohort Study. Journal of Cancer Survivorship, 9(1): 20-29.

Soliman, A. S., Mullan, P. B., O’Brien, K. S., Thaivalappil, S., \& Chamberlain, R. M. (2011). Career Development Needs Assessment in Cancer Prevention and Control: Focus on Research in Minority and International Settings. Journal of Cancer Education: The Official Journal of the American Association for Cancer Education, 26(3): 409-419.

Swanson, R. A., \& Holton, E. F. III (2001). Foundations of human resource development. San Francisco: BerrettKoehler.

Szilagy, I. S., Nagele, E., Furschuß, C., Mohapp, A., Wiegele, K., Lackner, H., \& Urban, C. (2019). Influencing factors on career choice and current occupation analysis of adult survivors of childhood cancer: a special focus on health-related occupations. memo-Magazine of European Medical Oncology, 12(1): 83-90.

Szymanski, E., \& Hanley-Maxwell, C. (1996), Career development of people with developmental disabilities: An ecological model, Journal of Rehabilitation, 62(1): 48-55.

Taskila, T., Lindbohm, M. L., Martikainen, R., Lehto, U. S., Hakanen, J., \& Hietanen, P. (2006). Cancer survivors' received and needed social support from their work place and the occupational health services. Supportive Care in Cancer, 14(5): 427-435. 
Taskila-Abrandt, T., Martikainen, R., Virtanen, S. V., Pukkala, E., Hietanen, P., \& Lindbohm, M. L. (2004). The impact of education and occupation on the employment status of cancer survivors. European Journal of cancer, 40(16): 2488-2493.

Upton, M., Egan, T. M., \& Lynham, S. A. (2003). Career development: Definitions, theories, and dependent variables. Proceedings of the Academy of Human Resource Development, USA: 728-735.

Van der Sluis, L., \& Poell, R. (2003). The impact on career development of learning opportunities and learning behavior at work. Human Resource Development Quarterly, 14 (2): 159-179.

Verdecchia, A., Guzzinati, S., Francisci, S., De Angelis, R., Bray, F., Allemani, C., \& EUROCARE Working Group. (2009). Survival trends in European cancer patients diagnosed from 1988 to 1999. European Journal of Cancer, 45(6): 1042-1066.

Verdecchia, A., Francisci, S., Brenner, H., Gatta, G., Micheli, A., Mangone, L., \& EUROCARE-4 Working Group. (2007). Recent cancer survival in Europe: a 2000-02 period analysis of EUROCARE-4 data. The lancet oncology, 8(9): 784-796.

Weinberger, L. A. (1998). Commonly held theories of human resource development. Human Resource Development International, 1(1): 74-94.

Wilkens, U., \& Nermerich, D. (2011). " Love it, change it, or leave it"-Understanding Highly-skilled Flexible Workers' Job Satisfaction from a Psychological Contract Perspective. Management Revue, 22(1): 65-83. 